Literature Reviews

\title{
Race and Consequences: An Examination of Police Abuse in America
}

\author{
${ }^{1}$ Nicole L. Martin and ${ }^{2}$ Augustine J. Kposowa

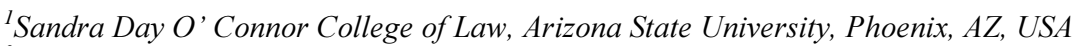 \\ ${ }^{2}$ Department of Sociology, University of California Riverside, Riverside, CA, USA
}

Article history

Received: 28-10-2018

Accepted: 25-01-2019

Corresponding Author:

Nicole Martin,

Sandra Day O' Connor College

of Law, Arizona State

University, Phoenix, AZ, USA

Email: nmart023@gmail.com
Revised: $05-12-2018$

\begin{abstract}
The past few years have witnessed numerous media images of law enforcement officers shooting and in many cases, killing unarmed African American men and women. In significant amount of the cases, despite overwhelming video footage, police officers have not been held accountable for their actions. Most of the incidents have involved White policemen killing African American men. The study aimed at determining the covariates of shootings. Using the Racial Threat Hypothesis, victim characteristics and incident characteristics are investigated with the aim of identifying common themes that emerge surrounding shootings. Data were obtained from media coverage including newspaper, television footage and the Mapping Police Violence Database. Content analysis was performed on the data in order to identify common themes present in the shooting incidents. Two police officers were interviewed in order to ascertain whether their responses were consistent with the themes that have risen regarding police abuse of African American citizens. A major theme that developed in nearly all incidents was efforts by both local officials and police departments to dehumanize the victims. A second theme that emerged was to blame the victim, often by exaggerating his or her ability to harm an officer. It was concluded that to end police violence, reform is needed that takes into account justice, fairness, racism and racial stereotypes.
\end{abstract}

Keywords: Law Enforcement, Police Shootings, Racism, Police Abuse, Violence

\section{Introduction}

The purpose of this study is to explain the incidence and prevalence of police violence. Recent police brutality cases have portrayed similar themes of African Americans being the prime targets, although they are unarmed. Police forces have not provided sufficient protection for African Americans. This lack of protection is primarily due to erroneous stereotypes of African Americans as being suspicious and threatening that have originated since the start of the Republic. The history of our nation has created the platform for the presence and tolerance of police violence. These stereotypes of African Americans have severe consequences for the treatment they receive from law officers and society as a whole.

Police violence is a prevalent issue across the nation. Racism has been justified through inadequate prosecution of officers who engage in targeted police violence. America's largest police departments have been the sites of numerous police abuse cases. According to the 2015 Police Report, "59 of the nation's largest 60 city police departments killed civilians in 2015" MPV (2015). Out of the 60 police departments, 41 of the departments killed Blacks at a disproportionate rate. There is a lack of research to explain this discrepancy that occurs nationwide.

Black people are three times more likely to be killed by police than White people. Thirty percent of Black victims were unarmed in 2015 compared to the $19 \%$ of White victims. African Americans were far more likely to be killed by America's largest city's police departments. Fourteen police departments including St. Louis, Atlanta, Kansas City, Cleveland, Baltimore, Virginia Beach, Boston, Washington DC, Minneapolis, Raleigh, Milwaukee, Detroit, Philadelphia and Charlotte-Mecklenberg, exclusively killed Black people in 2015 (MPV, 2015). 
The 2015 Police Violence Report (MPV, 2015) also reveals that community violence did not show an increase or decrease in police likeliness to kill people. A shooting death deprives the dead victim of the right of equal protection of the law. Although people often justify police use of force with the amount of crime in an area, research has shown that the community violence rates have not had an increase or decrease on the use of excessive force by law enforcement. Often community violence tends to be higher in areas where the population is of low economic status. This reveals that a bias can be present among the police force and African Americans are targets regardless of their neighborhood or socio-economic status.

Racism leads to excess policing where Blacks face the underserved consequences of being Black in the United States. Since the founding of our country, Blacks have not been protected. Thus, efforts must be made in order to ensure that Black lives are protected. Often in police violence cases, justice is not received and questions are left unanswered. Tension continues to build. It is difficult for a Black man or woman to feel as if they are exempt from this type of injustice, because this is nationwide; police violence can happen anywhere and at anytime.

\section{Literature Review}

There is a lack of research explaining the discrepancy between police shootings of Whites and Blacks. A study by Reisig and Terrill (2003) claimed that race did not play a statistically significant role in excessive use of force by officers. Rather, they found that "officers are significantly more likely to use higher levels of force when encountering criminal suspects in high-crime areas and neighborhoods with high levels of concentrated disadvantage independent of suspect behavior and other statistical controls" (Reisig and Terrill, 2003:17). When officers are in areas where there is heightened danger, they can be more likely to use excessive levels of force.

Terrill and Reisig also cited a study by Reiss and Bordua, which explained the 'dirtbag-syndrome.' This syndrome explained the behavior of police officers to place people into two categories. The first category included those viewed as deserving of punishment and the second category consisted of those undeserving of punishment. The people viewed as deserving to be punished are often called "dirtbags" by police officers (Reisig and Terrill, 2003:18). This study represents how when police officers enter neighborhoods that appear to be dangerous, they can already have a bias that some are deserving of police abuse, due to the area they reside. This presents a significant problem in how police officers perceive those who live in poor or dangerous neighborhoods. Often minorities are living in these poor areas, but not by choice. A majority of the people living in poor and high crime areas do not have the resources, security and financial stability to leave the area.

Terrill and Reisig left critical gaps in their study, which can flaw the credibility of their research. Terrill and Reisig, along with other researchers, often do not include historical factors that can explain why African Americans live in certain geographic areas. African Americans comprise a large percentage of the threatening areas that compose poor neighborhoods, which reveal a strong relation between one's race and their residence. However, Terrill and Reisig look at these two factors as distinct and separate from one another.

The research method used by Terrill and Reisig consisted of the Project on Policing Neighborhoods: Systematic social observations, census data, police crime records and in-person interviews with police officers (Reisig and Terrill, 2003: 8). "Twelve beats in each city (Indianapolis and St. Petersburg) were selected as study beats and observers were assigned to ride with the officers assigned to these beats" (Reisig and Terrill, 2003: 8). This presents a huge problem of credibility because the observers could only choose officers that were willing to participate in the study, which limited where their research could take place. It is also extremely unlikely for officers to discriminate based on race while being observed.

Other studies on police brutality have presented information that can easily be misinterpreted without providing context. For example, the Washington Post used a 2015 Fatal Police Shooting report, which revealed that 990 people were fatally shot by the police in 2015 . Of those killed, 561 were White and 289 were Black. One reading of these data might lead to the conclusion that Whites were killed at a higher rate than Blacks, although Blacks make up an extremely smaller percent of the population. This report also shows that in regard to weapons, 896 had a deadly weapon, 66 had a vehicle, 42 had a toy weapon, 101 were unarmed and 43 were unknown. Additional research must be completed and statistics need to be accessible to how many of those unarmed victims were Black as opposed to White to reveal potential bias.

Police presence typically is dispersed proportionately based on need and this need tends to be in low-income neighborhoods (Kposowa and McElvain, 2004: 266). The low-income neighborhoods were more likely to be comprised of minority populations. The public in minority neighborhoods filed complaints against police officers at a higher rate than those in less patrolled districts.

Graham $v$. Connor had a large impact on the allowance and justification of police abuse. Graham $v$. Connor, 109 S.Ct. (1872).

The court ruled that each case's individual facts need to be taken into consideration. However, regardless of the facts and circumstances of the case, similar results have occurred. Numerous citizens have 
suffered from police violence stemming from circumstances that were not severe.

The Supremacy Clause in the Constitution states the Constitution is the law of the land. (Article VI, Clause 2) Initially, African Americans were not included as citizens who were guaranteed fundamental rights and did not receive any benefits from being members of the United States. Slavery was admissible when the Constitution was written. The laws protected the slave owners, who viewed slaves as their property. In Dred Scott. v. Sandford, Dred Scott, argued to be a free man when he was in a free state. Dred Scott. v. Sandford, S. Ct. 60 U.S. 393 (1857). The Supreme Court ruled against Scott because the original framers of the constitution did not intend to give African Americans the rights that other citizens enjoyed. The Compromise of 1877 was an unofficial agreement that ended the Reconstruction era, pulled troops out of the South and appointed more Southerners as delegates. This agreement allowed the South to enforce segregation and racism. The Jim Crow laws emerged to deepen the division between Blacks and Whites. These laws left an impact on the superiority that whites had over Blacks.

The Reconstruction Amendments were created to give more rights to African Americans, but Whites were still able to participate in discriminatory acts without violating the amendments or the constitution. The Fourteenth Amendment states, "No state shall make or enforce any law which shall abridge the privileges or immunities of the citizens of the United States; nor shall any state deprive any person of life, liberty, or property without due process of law, nor deny any person within its jurisdiction the equal protection of the laws" (U.S. Const. amend. V). The Due Process Clause in the Fifth Amendment states, no person "shall be deprived of life, liberty, or property without due process of law" (U.S. Congress, 1866).

The State Action Doctrine revealed that Congress only had the power to protect against Fourteenth Amendment rights, which included state actions, rather than private actions. If a private person or entity was discriminatory, Congress was not given the authority to regulate these actions. Private discrimination was endemic during this time and numerous people were able to engage in discriminatory practices without being held responsible by the law.

New York "Stop and Frisk" gave police the right to stop residents who appeared suspicious. "The officer is entitled to protect not only himself, but the area" (Alexander, 2010:107). Officers were able to stop anyone and Blacks were the main targets of the Stop-and Frisk tactics. This became a normal procedure throughout various poor and minority areas. "If they are poor people of color, who tend to fear police harassment and retaliation, they are even less likely to complain"
(Alexander, 2010: 112). In January 2012, the police reported to make between $75-100$ stops per day in Brooklyn (Bostock and Fessenden, 2014). The basis for these stops was primarily based on race. African Americans appeared more threatening when compared to other races. Blacks were stopped and searched at an abnormally high rate (Bostock and Fessenden, 2014).

\section{Media}

The perceptions of crime and justice are influenced by how the interplay between criminals and victims are viewed socially and ethically by U.S. citizens (Barak, 1994:16). The media selectively chooses how individuals and groups of a specific classification are displayed. The media often portrays images of mainstream and uniform images of reality, rather than discussing "fundamental controversy" (Barak, 1994:10). News media often distorts issues concerning race, ethnicity, class and gender. Blacks are often portrayed in negative context especially in regards to crime (Barak, 1994:10).

Victim blaming plays a large role in justifying an officer's engagement in police violence. The Black victims who lost their lives to police violence are viewed as deserving of the punishment they received. The mainstream media is quick to destroy the victim's character in attempt to support the police's decision. The media will point to past mistakes the victim may have made to discredit their character and make the crime justifiable, which can pull the public's attention away from the true problem at hand. Demolishing one's character and focusing on their negative traits, can make people forget the significance of the case and the victim's life being taken.

\section{Theoretical Framework}

Race has a large effect on state-sanctioned control practices in U.S. social organizations. Blalock explains that Racial Threat Theory occurs when Whites uses their disproportionate power to implement state-control over minorities (Avery and Fine, 2012: 392). Blalock explains three forms of racial threat including economic threat, political threat and symbolic threat (Avery and Fine, 2012: 392). Economic threat arises due to the fear of White workers that believe minorities pose a threat to their job availably, job stability and wages. Political threat appears when White elites fear the loss of political power to minority groups. Symbolic threat emerges when Whites believe non-Whites are more susceptible to criminal or deviant behavior (Avery and Fine, 2012: 392). These three threats not only explain the tension and distress Whites can face when minority groups are present, but also justify the mass incarnation of African Americans. When the public views African Americans as inherently more dangerous to various aspects of 
society, the public displays a lack of empathy for African Americans being treated unjustly in the criminal justice system. There is a fear that Blacks will gain too much representation and negatively impact the society and culture based on American values.

\section{Methods}

We analyzed recent police brutality cases and the frame of the study focuses primarily on the past ten years. Police violence is not a new issue, but due to the rise of technology and media coverage, cases of police violence are more likely to be exposed. A pattern often exists within police violence cases. Typically, a minor incident, such as a traffic stop, escalates and the police officer uses force, which can end one' life. "Black men accounted for 40 percent of the 60 unarmed deaths" caused by police officers (Somashekhar et al., 2015). One is armed if they have a deadly weapon or object that could inflict fatal injury on to another in their possession (Somashekhar et al., 2015). The claim that police are being threatened by unarmed Blacks reveals a discrepancy in how law enforcement views Blacks and Whites.

\section{Results}

\section{Case 1: Michael Brown}

Michael Brown, an unarmed African American teenager was shot to death in Ferguson, Missouri. The media has brought up past mistakes the victim may have made in attempts to discredit their character and make the crime justifiable. The media pulled the public's attention away from the true problem at hand. In Michael Brown's case, the media focused on Brown stealing from the store, which was not relevant to the shooting. The emphasis the media placed on his stealing was an attempt to justify the shooting that occurred. Demolishing one's character and focusing on their negative traits can make people forget the significance of the case and the victim's life being taken.

In Ferguson, Missouri Major James Knowles III suggested that recruiting more African American officers and creating a civilian review board would help monitor police conduct. The mayor stated that adding more African American officers to the predominantly White police force would improve the relations between the police department and the African Americans living in Ferguson. However, the mayor claimed there would be not be any imminent changes in the leadership in the police department after the grand jury made the decision to not indict Darren Wilson, the officer who killed Michael Brown. The grand jury was composed of nine Whites and three Blacks.

Wilson claimed that his life was in danger, although Brown was unarmed. The mayor claims he wants to help protect the people of Ferguson, but did not give Wilson a deadline to resign (Lee, 2014). Wilson did not receive any punishment for taking the life of Michael Brown. His death "reflects a pervasive, deep-seated reliance on dehumanizing stereotypes: Black men are dangerous, violent and criminally inclined" (Banks, 2014). Michael Brown's physical characteristics were defined in a way to make him seem animalistic and dangerous. Wilson's testimony sounded like a "jungle encounter" referencing Brown to appear as a "beast making animal noises" (Banks, 2014). However, Brown's size and weight were not the reasons he lost his life. Brown's life was taken because he was Black male treated unjustly by police.

\section{Case 2: Eric Garner}

Eric Garner was killed on July 17, 2014 in Staten Island, New York (Harkinson, 2014). Eric Garner was a 43-year-old Black male, who was confronted by the New York City police officers for selling untaxed cigarettes. Garner was an asthmatic father of six and was placed in a chokehold and killed by police officer Daniel Pantaleo (Harkinson, 2014). The grand jury also made the decision to not bring criminal charges against Pantaleo. Garner's last words were "I can't breathe!" Placing one in a chokehold is a tactic that was banned by the department in 1993 and Garner's death was due to the neck compression of the chokehold.

\section{Case 3: John Crawford}

John Crawford, a 22-year old Black male was killed due to police violence on August 5, 2014 in Beavercreek, Ohio inside Walmart. A 911 phone call was made about a man waving a gun inside a Walmart store (Harkinson, 2014). The gun they referred to was Crawford's. 177 calibre BB rifle that he had picked up from Walmart's store shelf.

The video released of Crawford's shooting contradicts the police's version of what occurred. The police stated they shot Crawford after repeatedly demanding him to drop the rifle. Yet, the footage shows Crawford being shot shortly after encountering the officers (Balko, 2015). The video also proves that Crawford did not point the gun at anyone, which drastically differs from what the witness told a 911 dispatcher. The witness alleged that Crawford pointed his gun at children and the witness repeated this statement to the media as well (Balko, 2015). The witness later changed his story after viewing the surveillance video.

LeeCee Johnson, Crawford's mother, was on the phone with Crawford when he was shot. LeeCee explained that Crawford told her he was in the toy section at Walmart, which contained toy guns. She heard her son say "It's not real" and the police started shooting (Balko, 2015). The police told Crawford to get on the ground, after he had already been shot and was lying on 
the floor. There was no attempt by the police to deescalate the situation.

\section{Case 4: Ezell Ford}

Ezell Ford, a 25-year-old Black man, was shot in the back and killed in Los Angeles, California on August 11, 2014 (Harkinson, 2014). Before his murder, the police conducted an investigative stop of Ezell. Around 8:00 PM, two officers with LAPD's anti-gang unit confronted Ford as he was walking in his neighborhood. Officer Sharlton Wampler claimed he wanted to talk to Ford, but Ford continued to walk (Brumfield, 2015). The officers declared they had reasonable suspicion to detain Ford due to the area being known for gang and drug activity. They reported that Ford seemed nervous. Wampler caught up to Ford, touched his shoulder and attempted to handcuff Ford. According to Wampler, Ford responded by tackling him and ended up on top Wampler, with control of his gun (Brumfield, 2015). Officer Antonio Villegas fired at Ford twice and Wampler reached over Ford's back to also shoot Ford. Ezell died in a hospital from his wounds and his family stated that he was mentally ill (Brumfield, 2015). Ezell was killed two days after Michael Brown. Because of the protests that followed in Ferguson, Ezell's death was not widely covered.

A civilian committee who was responsible for the oversight of the Los Angeles Police Department revealed an unanimous vote that one of the officers involved in the shooting acted against police department policy in the officer's approach to Ezell, how the officer scuffled with him, how he drew his gun and the shooting of Ezell (Brumfield, 2015). The Los Angeles Board of Police Commissioners believed the other officer involved was also unjust in how he initially drew his gun, even though it was ruled in department policy when he fired on Ford (Brumfield, 2015). This ruling was based on the officer's decision to shoot Ford when he saw his partner and Ford fighting with one another. The committee professed Wampler erred in suspecting and detaining Ford and also found Villegas to be wrong for drawing his gun when the officers initially approached Ford (Brumfield, 2015).

Officer Wampler, a 12-year department veteran and Officer Villegas, who worked with the department for 8 years, broke various police policies in the confrontation with Ford, which resulted in Ford's death (Brumfield, 2015). Officers who have been working for several years with the department, should not only be fully aware of the rules and policies of the department, but should be complying with these standards. Police Chief Charlie Beck and an independent investigator gave two prior assessments, which found the police to not be at fault for Ford's death (Brumfield, 2015).

The story told by the officers drastically differs from the stories told by the witnesses. A family friend of Ford witnessed part of the incident and reported that she did not witness any struggle between Ford and the officers (Johnson, 2014). Ford's cousin stated that Ford was laid out and shot in the back and mentioned that all officers in the area were aware of Ford's mental problems. Ford's parents said Ford was diagnosed with depression, schizophrenia and bipolar disorder (Johnson, 2014). Ezell's mother stated that he was lying on the floor complying with the orders of the officers when he was shot and killed (Harkinson, 2014).

The media also attempted to diminish Ezell's character and justify the situation. The Los Angeles Times reported that Ford had previous convictions for possession of marijuana and illegal possession of a loaded firearm (Johnson, 2014). These statements were made to change the public's perception of Ford and created an image of him being dangerous and harmful. However, the day of Ford's death, no drugs were found on him (Brumfield, 2015).

\section{Case 5: Samuel DuBose}

University of Cincinnati, Officer Ray Ten Tensing, shot and killed Sam DuBose, an unarmed Black man, during a traffic stop. Tensing intended to stop DuBose for missing his front license plate (Blow, 2015). Speculations were made that Tensing lost his temper since DuBose would not get out of the car and was quick to pull out his gun and shoot DuBose in the head (London and Hagrman, 2015). DuBose's family stated that DuBose was in frail health. Due to his health conditions, he would not have been able to resist the officer or quickly exit the car (London and Hagrman, 2015).

According to the information report regarding DuBose's shooting Office Tensing's stated, "he almost was run over by the driver of the Honda Accord and was forced to shoot the driver with his duty weapon" (Blow, 2015). He also claimed he fired one single shot and was dragged by the vehicle, which forced him to fire his weapon. The video, however, proves each of these claims to be false. The body camera video was a critical component of Sam DuBose's case, which proved the false statements made by Officer Tensing.

Prosecutor Deters explained that DuBose did not act aggressively toward Officer Tensing. He clarified that Officer Tensing was not dragged on the floor, but fell backwards once he shot DuBose in the head. Deters also commented on Tensing's attempt to mislead investigators from looking into the incident. DuBose's family attorney, O'Mara, discussed how quickly the shooting occurred. When watching the video, O'Mara stated she was waiting to see the escalation of the event and was surprised how quickly the shot happened and the car immediately took off.

\section{Case 6: Laquan McDonald}

Laquan McDonald, a seventeen-year-old Black male, was killed by Chicago police Officer Jason Van 
Dyke on October 20, 2014. Van Dyke had a history of complaints during his years as an officer (Fantz, 2015). The complaints primarily consisted of Van Dyke using excessive force and he once was accused of using a racial slur (Fantz, 2015). Van Dyke was cleared in a majority of these cases. Due to Van Dyke's use of excessive force during a traffic stop, the jury awarded a man in Chicago $\$ 350,000$. Van Dyke's previous behavior appears reflective to his decision to repeatedly shoot Laquan. Laquan was shot sixteen times. There is no justification for one officer to fire sixteen shots on any person, especially a person who did not pose a threat to Van Dyke's life. Video footage revealed that Laquan was walking down the street, away from the officers. Police later stated McDonald was carrying a 4-inch knife. Among at least eight officers, Van Dyke was the only officer to fire his gun. However, McDonald's back appeared to be toward the police cars when he was shot.

Officer Van Dyke, "the first officer to be charged of first-degree murder since 1980", was found guilty of second-degree murder. (CNN Wire, 2018). Van Dyke "was found guilty on 16 charges of aggravated battery with a firearm, one for each shot fired at McDonald." (Guarino and Berman, 2018).

\section{Case 7: Tamir Rice}

Tamir Rice was a 12-year-old child who lost his life in seconds to police violence. A settlement was made with Tamir's family and the City of Cleveland, where the city of Cleveland will pay $\$ 6$ million to Tamir's family in response to the federal lawsuit that they filed (Pearson, 2016). The terms of the settlement did not cast blame on the city in Tamir's death. Preceding Tamir's death, a 911 caller, stating that Tamir was in the city park with what appeared to be a toy gun. Officer Timothy Loehman, a trainee, shot and killed Tamir after the phone call was made. The grand jury failed to indict Officer Loehmann or his trainer, Officer Frank Garmback. The grand jury proclaimed that the shooting of Tamir was not a criminal act, but rather a "perfect storm of human error, mistakes and communications" (Pearson, 2016).

The wrongful death lawsuit brought about by Tamir's family argued the city displayed negligence and the dispatchers should have explained to the officers that Tamir likely possessed a toy gun. Tamir's family stated the "officers approached the scene too aggressively and Loehmann fired too quickly and that they failed to help the boy after he was shot" (Pearson, 2016). In addition, Tamir's family also declared Loehmann was ill-suited to be a police officer and there was a lack of action by the city to properly supervise officers. The city responded by placing blame on Tamir, rather than the city. The city claimed they were entitled to immunity under state and federal law (Pearson, 2016).

\section{Case 8: Sandra Bland}

Although most cases of police violence typically involve Black males, Black women are also victims of police violence. Sandra Bland, for example, was a victim of police brutality whose life was taken by the law enforcement. Sandra Bland was stopped during a traffic stop, beaten by the police and arrested (Stanford, 2015). During her arrest, Bland yelled for the officer to stop hitting her and that the officer was crushing her ribs. Bland was found dead in her cell in Waller County Texas (Stanford, 2015). In Texas, grand jurors did not indict any of the officers in connection to Bland's death, including Trooper Encinia, who initially pulled Bland over during the stop.

\section{Case 9: Freddie Gray}

In Baltimore, Freddie Gray lost his life due to police violence on April 19, 2015. Gray was a 25-year old African American male who also experienced spinal injuries as he was being arrested. The mayor of Baltimore, Stephanie Rawlings Blake, has lobbied to give the police commissioner more power to discipline officers. Baltimore has recorded 107 homicides within the last year. Baltimore officials state the most effective way of preventing police violence was through training. Police Commissioner Anthony Batts suggested officers wear video body cameras. Batts also wanted to negotiate with the police union to be able to punish officers quickly for their offenses involving police violence.

\section{Case 10: Steve Eugene Washington}

In 2010 a jury awarded nearly 4 million dollars to two Los Angeles cops George Diego and Allan Corrales, who shot and killed, Steve Eugene Washington, a 27-year old autistic Black man (Hanson, 2015). According to the lawsuit, this was an act of retaliatory discrimination. The officers claimed Steve gave them a "blank stare", which the cops regarded as suspicious activity (Hanson, 2015). Steve reached into his waistband to grab his cellphone and was shot in the head. The only punishment of this unlawful killing was subjecting the officers to desk duty.

\section{Case 11: Stephon Clarke}

Stephon Clarke was shot and killed by Sacramento police officers on March 18, 2018 at his grandmother's house (Levenson et al., 2018). The fatal shooting was recorded by the officer's body cameras and from a police helicopter. Officers responded to a report stating that a man had broken car windows and was hiding in his backyard (Levenson et al., 2018).

Officers arrived at the front yard and chased Stephon. The Officers claimed that Stephon was pointing what appeared to be a firearm at them. The officers then fired twenty shots at Stephon and he was hit multiple times (Levenson et al., 2018). 
Stephen was pronounced dead at the scene. Stephon was unarmed and the object in Stephon's hands the officers were referring to was Stephon's cell phone (Levenson et al., 2018). The officers responsible for Stephon Clarke's shooting returned to work. Police told $\mathrm{ABC}$ the names of the officers involved have not been released and that there are no plans to release their names (Ayyoub, 2018).

\section{Interviews}

Author 1 interviewed two minority police officers. Officer 1 has been working for the police department for three years now. A majority of Officer 1's family has been in law enforcement. Officer 2 has been working as a police officer for 28 years. These interviews help give a better understanding on the differing views of how these officers view police violence and police brutality issues.

When asked what role cultural diversity plays in police training, Officer 1 responded, by saying "various presentations are provided daily by an officer, sergeant, or director, in regards to cultural diversity, morals and ethics."

Author 1 asked Officer 1, when an officer is advised to use lethal force. Officer 1 said, "When you shoot, you shoot to kill. Using your gun is the last resort."

When asked about discrimination towards minority citizens, Officer 1 said, "It goes back to demographics, who the community is composed of and who is causing the crimes. In my department Mexican and Blacks are the ones typically causing crimes."

Author 1 asked, "Are the officers informed on the recent police brutality cases that have occurred?" Officer 1 exclaimed, "We are constantly made aware of the recent cases and are called into briefings that occur before every shift." During these briefings, the officers watch videos of current cases, where a cop was either performing very well or extremely poorly. During these briefings, the videos are often paused or rewound to look carefully at the officer's actions. Officer 1 indicated that "most of it is happening on the east coast or in the south. Not so much is happening in California."

Author 1 then asked, "If officers are repeatedly informed of the mistakes and correct protocol to take during situations, why are so many cases of police brutality still occurring?"

Officer 1 responded by stating, "the media blows up small things and make it huge". Officer 1 also shared that "officers are humans too, with human emotions and have to make quick responses." Although the officers are watching videos of other officers making clear mistakes against their codes and protocol, "every job is going to have people that are not so great that make bad decisions."

When asked, about the victims whose lives have been lost to police violence, Officer 1 defended the officers by stating, "It could have been a simple mistake and law enforcement is a difficult profession, which requires one to make difficult decisions."

When discussing the lack of trust the public has with law enforcement, he explained how the recent recording of officers, will start to change the interactions of the officers for the better. "Training is going to keep getting better. New waves of officers are coming in and the generations are changing." Officer 1 then explained how officers are being recorded, critiqued and watched critically, which is a different experience than the older officers dealt with. Officer 1 also explained how departments are starting to look for more educated students who have obtained college degrees.

From our interview too large of an emphasis was placed on police violence being a mistake. The officers committing these acts of violence are aware of what they are doing. The law enforcement is inclined to protect their fellow officers. The comment stating that police brutality cases being not likely to happen is California, is a statement of denial and refusal to accept that police violence is occurring in California.

Officer 2 is African American and began to express his frustration with the Black community. Officer 2 explained how there are many "bad seeds and bad apples in the Black community." Yet, Officer 2 mentioned the social struggles that African Americans often face such as coming from broken homes, not having their father around, or not having mentors to guide them in the right direction. Officer 2 explained how the Black youth become a part of a vicious cycle that is often exposed to violence. However, Officer 2's frustration with the Black community stemmed from his negative encounters with Blacks while on duty.

Author 1 asked, "What are your thoughts on recent police violence cases that have occurred?"

Officer 2 stated, "I believe the media blows the cases out of proportion and exaggerate." Officer 2 explained that when they are on camera, the public is more likely to be hostile and argumentative. When pulled over, Officer 2 stated, "Blacks are looking to complain and start conflict with the police." However, Officer 2 did not ignore the fact that discrimination exists in the law enforcement.

Officer 2 was raised in the Black community and stated that has an effect on his actions while on duty. Officer 2 explained that other officers come to areas in poor neighborhoods to learn how to deal with different crimes. Officer 2 stated that some officers drive 50 miles a day just to work in these stations that are known to be minority areas because they know they will be more likely to get away with mistreating those in the Black community. Leading off of this statement, I stated that many people feel as if the police are engaging in these acts of violence that result in the loss of one's life because they know they will not be penalized. Yet, Officer 2 protected the law enforcement by stating that police sacrifice their lives for the public 
and would never kill someone just because they knew they could get away with it. However, Officer 2 did state that if a person "looks dirty" or "smells marijuana" they would be pulled over.

Officer 2 stated its time for people to take responsibility for their own actions. Officer 2 began explaining that people need to look more at themselves and demand respect by their actions. Officer 2 mentioned Blacks youth physical appearance, such as tattoos and stated that one's appearance can make them more likely to be pulled over. He stated there are ways to avoid being pulled over by the police, such as not having their music blasting or having tattoos on their face and neck. This focus on physical appearance ties into an officer believing that one looks suspicious and confirms the emphasis placed on physical characteristics discussed with Racial Threat Hypothesis.

When Author 1 asked whether he believed that hiring more minority police officers would decrease police violence cases, Officer 2 responded by saying, "including more minority police officers will allow for a better understanding of the struggles minorities face." The next question was "Why do you think there a lack of minority officers?" Officer 2 stated, "Departments do not hire them. Minorities are more likely to be failed out of the testing process."

Officer 2 elaborated on this statement and stated a Black person will be failed by the department for smoking marijuana, but a White applicant who smoked marijuana will still be hired. Officer 2 also explained how many departments are discouraged to hire Blacks and only will hire Blacks to fit the quota. Officer 2 knows of a department where the captain instructed his lieutenant to hire enough Blacks to fit the quota and then stop hiring them once the quota is filled. Officer 2 also explained that being a police officer takes discipline and Black youth are not able to discipline themselves enough to become an officer.

Officer 2 raises several issues of concern. Primarily, there is more of a blame placed on the Black community than the law enforcement for issues of police violence. Although Officer 2 acknowledges that racial discrimination exists, the officer did not address that racial discrimination exists in relation to police violence. Rather than addressing the issue where police target African American youth, Officer 2 justified the issues of police violence by placing the blame on the African American youth itself. Officer 2 discussed how that Black community is negatively perceived among officers due to the experiences they have encountered. However, these negative experiences are engraved into the officers' minds, which allow them to justify the mistreatment and excessive use of force among Blacks.

\section{Discussion}

With the technological advances including internet, cameras and cell phones, the media has carefully selected what to show to the public. When police violence cases occur, the media shifts the focus of the victim to the riots and property damages that have occurred. This stress on property damage adds to the media's construction of Black being dangerous and posing threats to one's security and safety. The media is quick to call a group of Blacks together rioters, even if they are peacefully protesting.

Similarities are presented throughout these cases of police violence. The victims of police violence were unarmed and the police had alternative options rather than to end their lives. In several of the cases, the police resorted to using excessive force rather than other tactics. Often times the police tried to justify their behavior by stating the victim looked suspicious. This suspicion the police refer to originates from stereotypes that were created during the antebellum period to oppress Blacks. Police officers comprise a small group of people who are given permission to take another's life without being penalized. With this permission, numerous police have been abusing their power. Officers are letting their own beliefs, stereotypes of Blacks and discriminatory attitudes affect their decision in treating Blacks. Blacks do not receive the same treatment and respect as citizens of the United States. Rather, African Americans are treated as a group that needs to be controlled. From the foundation of the Republic to the present, Whites have tended to use police forces as weapons against African Americans, often out of racial hatred and outright malice.

\section{Policy Implications}

Reform is necessary in order to improve the relationship between the law enforcement and the public and to prevent cases of excessive force by officers. An establishment of national and regional review boards should be created. The national review board should be in charge of oversight and supervision of the regional review boards. The review boards should be representative of the U.S. population with regard to race, ethnicity and gender. The regional review board should investigate the case and should have subpoena powers who are able to call people to testify under oath, including police officers. The board's mandate must clearly be specified and should be transparent to the public, which will allow the public to have a better understanding on what the review board is allowed to do.

The review board should issue a report at the end of their investigation. If the review board makes the decision that an officer killed without just cause, the board should recommend that the case be brought to trial. The decisions of the review board should be binding. To maintain strict neutrality, it would be ideal to have a non-salaried board. Members may be paid honoraria for their period of service, but not be based on permanent salaries. 
Trust is a huge issue that arises between the public and law enforcement. The police department needs to be held accountable for their officer's failing to follow proper procedures. The public will be more willing to trust the officers if they know that their actions are being recorded. Although many departments have implemented the use of body cameras, all departments should be required to do so. The recordings should be kept on record by the police department. However, when a police shooting occurs, the review board should review the video footage. The presence of body cameras will be likely to prevent officers from acting against department policy. The public often does not feel that the criminal justice system is protecting citizens. Rather, many believe that law enforcement is better protected than the people, which weakens their trust in the law enforcement. When constitutional issues have arisen regarding excessive use of force, the public has witnessed numerous officers receiving no indictment.

Surveys should also be conducted by the regional board to hear the public's view of the law enforcement officers. Often many people may not report their incidents of excessive force to the police because they are either intimidated or not confident that any change would occur. Having an anonymous survey allows the public to participate in voicing their issues and encounters with the police officers. However, although bias can be present in surveys or in some cases subjects may not recall accurately, continuous reports or complaints of inappropriate behavior by the same officers should be noted. If feedback from the survey reveals that specific officers have been acting out of compliance and using excessive force, then an investigation should follow.

Law enforcement officers should be held to higher standards in regard to engaging in discriminatory behavior for the simple reason that they have been entrusted with authority and this should not be used illegitimately. Law enforcement officers are given power that ordinary civilians do not possess. In order to help prevent police violence against African Americans, law enforcement needs to have stricter punishment for participating in discriminatory acts.

Police officers have legal authority to use force when they feel it is necessary, without being penalized. All too often, US police forces tend to escalate conflict instead of deescalating them. Thus the force used can include handcuffing, chemical agents and use of weapons. This power can be extremely dangerous when given to the wrong people especially in a career where the officers must make split second decisions. Racial Threat Hypothesis helps explain the fear the law enforcement and public have of Blacks. Although this fear has been systemically created over time, Blacks face harsh consequences they do not deserve. New policies are imperative in the United States to reduce the number of Black lives that are lost to police violence and abuse of power. The nation cannot afford to proceed without addressing potential dangers that may loom ahead.

A second theme that emerged was to blame the victim, often by exaggerating his or her ability to harm an officer. It was concluded that to end police violence, reform is needed that takes into account justice, fairness, racism, and racial stereotypes.

\section{Conclusion}

African Americans across the nation can be subject to prejudice treatment by law enforcement officials. Negative stereotypes of African Americans have persisted for hundreds of years, which have affected the mass number of African Americans who have lost their lives due to police abuse. Policy implications are necessary for African Americans to be treated fairly as a citizen on the United States, rather than being viewed as a threat. Law enforcement officers must be held accountable for their actions and preventative measures must be taken to decrease the amount of police violence against African Americans.

\section{Acknowledgment}

We wish to acknowledge the sacrifices made by all Black people who have devoted their lives to fighting police injustice.

\section{Author's Contributions}

Nicole L. Martin: Wrote the initial draft of the manuscript. She identified themes that tend to emerge in police shoothings and other anti-civilian violent encounters. He arranged the tow interviews, conducted and transcribed what the two police officers said.

Augustine J. Kposowa: Read the first draft and devised the research plan of the article. He coordinated the data analysis and interpretation, contributed to the writing of the manuscript and did serveral reviews for clarity. Both authors take full responseibillity for the content of the article and all errors are theirs alone and the Journal of Social Sciences.

\section{Ethics}

This article is original and contains unpublished material. The corresponding author confirms that all of the other authors have read and approved the manuscript and there are no ethical issues involved.

\section{References}

Alexander, M., 2010. The New Jim Crow: Mass Incarceration in the Age of Colorblindness. 1st Edn., The New Press, New York, ISBN-10: 1595581030, pp: 290. 
Avery, J. and J. Fine, 2012. Racial composition, white racial attitudes and black representation: Testing the racial threat hypothesis in the United States senate. Political Behav., 34: 391-410. DOI: $10.1007 / \mathrm{s} 11109-011-9173-\mathrm{x}$

Ayyoub, L., 2018. Officers who fatally shot stephon clarke return to work. ABC News.

Balko, R., 2015. Mass shooting hysteria and the death of John Crawford. Washington Post.

Banks, S., 2014. Police expectations damage black men's realities. Los Angeles Times.

Barak, G., 1994. Media, Process and the Social Construction of Crime: Studies in Newsmaking Criminology. 1st Edn., Garland Pub., New York, ISBN-10: 0815312598, pp: 322.

Blow, C.M., 2015. The shootings of samuel DuBose. New York Times, New York.

Bostock, M. and F. Fessenden, 2014. Stop-and-Frisk' is all but gone from New York. The New York Times. http://www.nytimes.com/interactive/2014/09/19/nyr egion/stop-and-frisk-is-all-but-gone-from-newyork.html? $\mathrm{r}=0$

Brumfield, B., 2015. Ruling: Officers who killed ezell ford violated policy. Cable News Network.

Fantz, A., 2015. Chicago cop pleads not guilty in Laquan McDonald Killing. CNN, Cable News Network. http://www.cnn.com/2015/12/29/us/jason-van-dykechicago-police-laquan-mcdonald/

Hanson, H., 2015. LAPD officers who shot unarmed man with autism awarded millions in discrimination lawsuit. The Huffington Post.

Harkinson, J., 2014. 4 unarmed black men have been killed by police in the last month. Mother Jones.

Johnson, T., 2014. Ezell ford: The mentally ill black man killed by the LAPD two days after Michael brown's death. Washington Post.
Kposowa, A.J. and J.P. McElvain, 2004. Police officer characteristics and internal affairs investigations for use of force allegations. J. Crim. Justice, 32: 265-279.

Lee, K., 2014. Ferguson police to seek more black recruits; no severance for Darren Wilson. Los Angeles Times.

Levenson, E., M. Park and D. Simmon, 2018. Sacramento police shot man holding Cellphone in Grandmother's Yard. CNN.

London, J. and M. Hagrman, 2015. Prosecutor officer ray tensing indicted on Murder Charge in death of Sam Dubose. WLWT News.

MPV, 2015. Police Violence Report". Online Database. Mapping Police Violence. http://mappingpoliceviolence.org/2015

Pearson, M., 2016. Tamir rice shooting lawsuit settled for $\$ 6$ million. Cable News Network.

Reisig, M.D. and W. Terrill, 2003. Neighborhood context and police use of force. J. Res. Crime Delinquency, 40: 291-321.

Somashekhar, S., W. Lowery, K.L. Alexander, K. Kindy and J. Tate, 2015. The 24 unarmed black men who have died in 2015. Washington Post.

Stanford, J., 2015. The Sandra bland investigation is in trouble. Huffington Post.

U.S. Congress, 1866. Statutes at large of the United States. https://memory.loc.gov/cgibin/ampage?collId=llsl\& fileName $=014 / 11$ s1014.db\&recNum $=389$

CNN Wire, 2018. Chicago police Officer Jason Van Dyke found guilty of second-degree murder in Laquan McDonald killing. Fox 13 Salt Lake City.

Guarino, M. and M. Berman, 2018. Chicago police officer Jason Van Dyke convicted of second-degree murder for killing Laquan McDonald. 